\title{
Anti-marketing of Drug Abuse by Means of Grounded Theory
}

\section{Ghasem Zarei}

* Associate Professor, Department of Management, Fatulty of literature and humanities, University of Mohaghegh Ardabili, Ardabil, Iran. (Corresponding author): info@drgz.ir

Tahereh Zarei

Instructor, Department of nursing, Sarab Faculty of Medical Sciences, Sarab, Iran

Soraya Farajzadeh

MSc Student, Department of Management, Fatulty of literature and humanities, University of Mohaghegh Ardabili, Ardabil, Iran

Received: 06 February 2019

Accepted: 20 July 2019

DOI: 10.30699/ijhehp.7.3.373

\section{ABSTRACT}

Background and Objective: Nowadays, arbitrary drug use is one of the most important problems in the world, including Iran. Due to the harmful effects of drug abuse, this study aimed to assess the cause of arbitrary use of drugs and anti-marketing strategies for drug use among Referrals to medical centers of social security organization in Ardabil.

Materials and Methods:This is an applied, objective and a qualitative research in terms of the nature of the research. In this study, the data from interviews with 21 patients and physicians of the Social Security Clinic of Ardabil city were analyzed using the Grounded Theory Method in three stages (open coding, axial coding and selective coding).

Results: The findings of this study showed that the causes of drug abuse are in six areas of economic, access, cultural-social, barriers related to health centers, awareness, experience and attitude.

Conclusion: According to the findings of the research, the Ministry of Health, health centers and other related areas should plan on reducing the effects of identified factors on drug abuse. This is possible through reducing the cost of treatment, increasing the coverage of the health centers in terms of geographical coverage, and mass media campaigns in the area of education and informing the society. Keywords: Drug abuse, Anti-marketing, Grounded theory Paper Type: Research Article.

Citation (Vancouver): Zarei Gh, Zarei T, Farajzadeh S. Anti-marketing of Drug Abuse by Means of Grounded Theory. Iran J Health Educ Health Promot. Autumn 2019;7(3): 373-383. [Persian]

- Citation (APA): Zarei Gh., Zarei T., Farajzadeh S. (Autumn 2019). Anti-marketing of Drug Abuse by Means of Grounded Theory. Iranian Journal of Health Education \& Health Promotion., 7(3), 373-383. [Persian] 


\section{ضدبازاريابى علل مصرف خودسرانهُ دارو با استفاده از رويكرد تئورى دادهبنياد}

\section{بكاند}

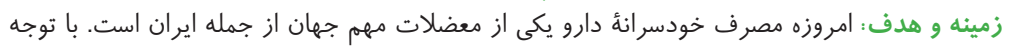

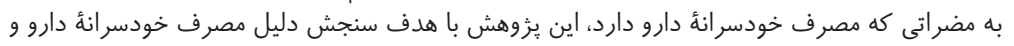

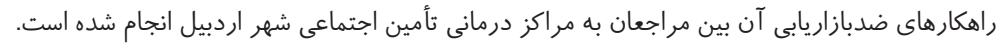

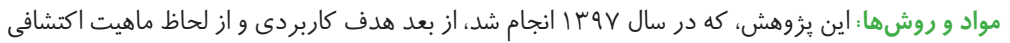

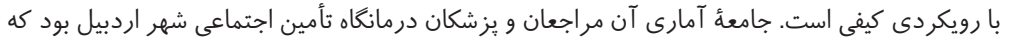

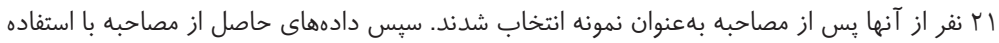

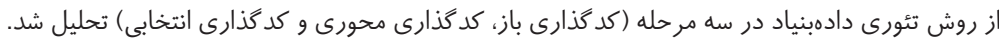



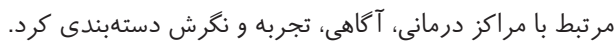

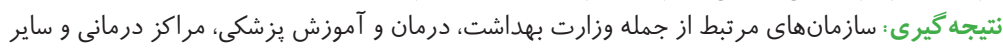

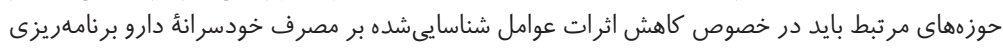

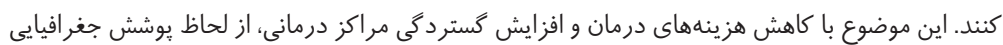

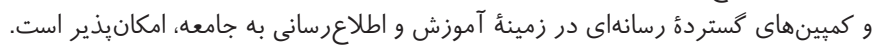

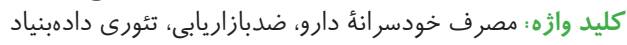

نوع مقاله : مطالعه يزوهشى.



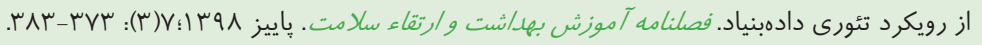

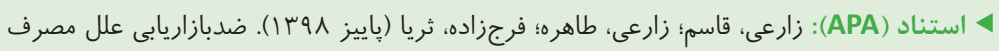

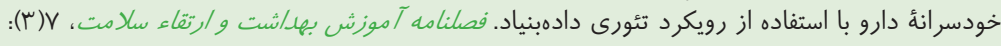

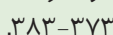

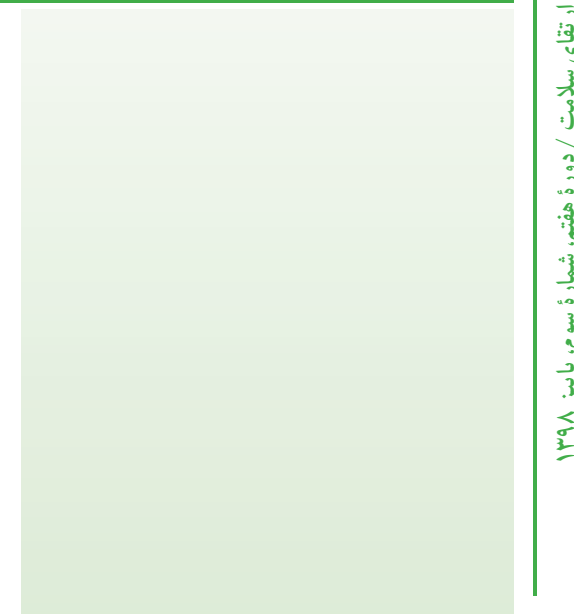

* * دانشيار كروه مدير ماريت بازركاني، دانشكده ادبيات و علوم انسانى، دانشخاه محقق اردبيلى، اردبيل، ايران.

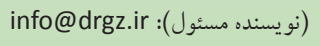

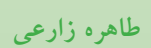
مربى گروه يرستارى، دانشكدة علوم يز شكى سراب،

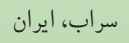

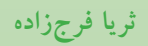
دانشجوى كارشناسى ارشد كروه مديريت بازر كانى،

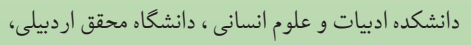

اردبيل، ايران

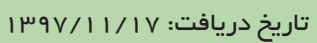
تاريخ يذيرش: تاري: 
امر به ايجاد مقاومت باكتر يايى، درمان نامناسب، مسموميتهاى

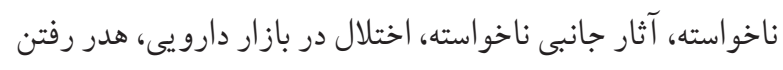

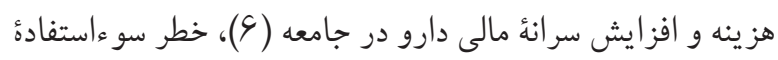
مجدد، استفادءٔ بيشازحد و طولانى مدت از دارو، تأخير احتمالى در درمان يك بيمارى جدى، مخفى شدن نشانهايى از يك بيمارى

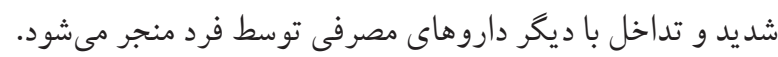

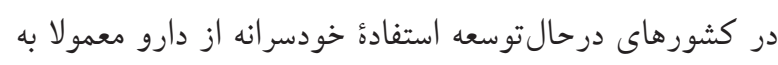
الكوهاى نامناسب استفاده از مواد مخدر نيز منجر مى شود (11)

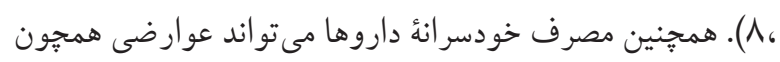

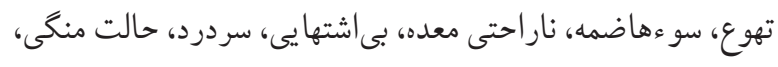

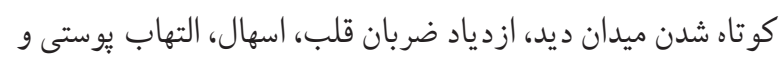

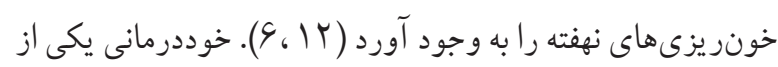

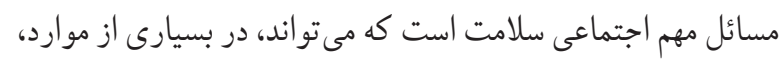

معضلات مهمى براى فرد و جامعه ايجاد كند (9). مصرف نادرست دارو معضلى جهانى است و در سراسر دنيا فرداد

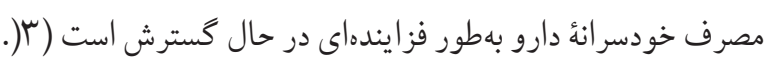
يثوهشهاى علمى و آمارها نشان مىدهد كه الحوى مصرف دارو، براى گروههاى مختلف درمانى، در ايران از معيارهاى استاندارد

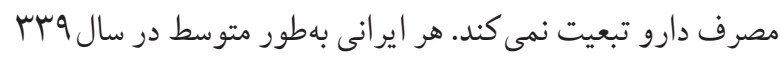



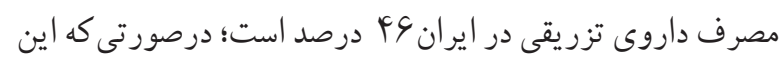

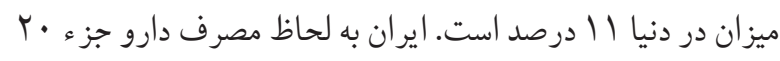

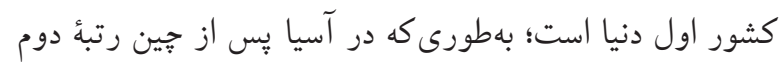

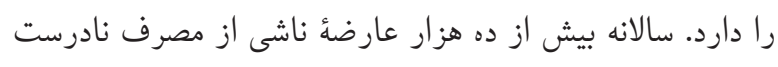
دارو گزارش مىشود (11). طى دهو كذشته مصرف دارو بهعنوان

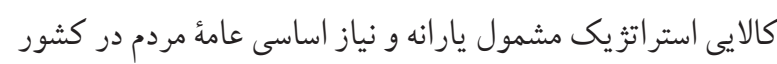

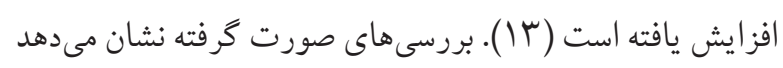

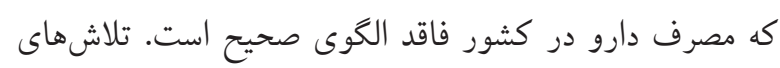
صورت گرفته براى اصلاح اين الخو موفقيت جندانى نداشته و نظام

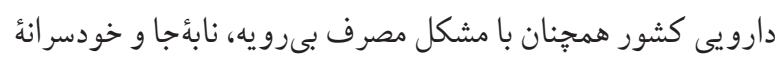

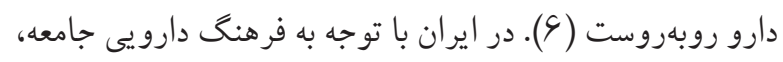
كالاها و خدمات زيادى هستند كه ممكن است تقاضا براى آنها از نظر سلامت مصرف كننده و جامعه ناسالم تشخيص داده شوند (1). ضدبازاريابى تكنيكى براى غلبه بر رفتارها و تقاضاهاى ناسالم مصرفكنندگان است و نوعى مبارزه با مصرف را براى برخى از

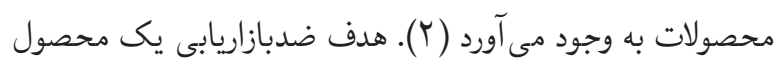

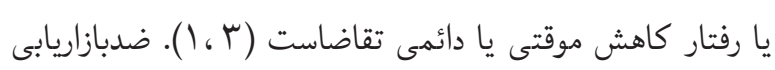
در اصل فنى ارزشمند براى مبارزه با تقاضاهاى ناسالم است (Y).

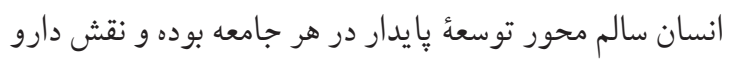
در اين ميان اساسى است (ه). تهيه، توزيع و مصرف صحيح دارو

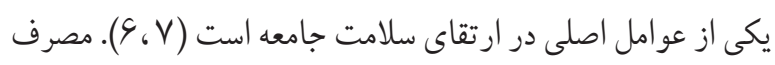

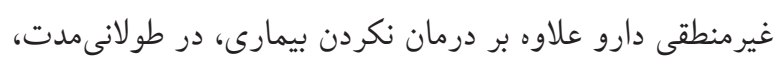

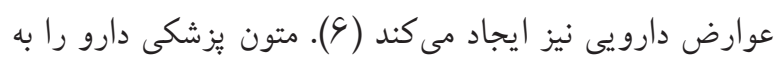

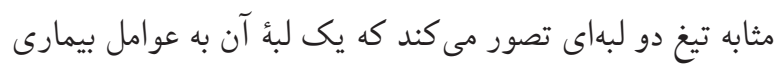

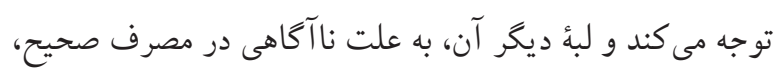

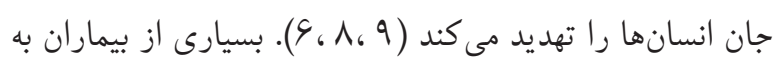



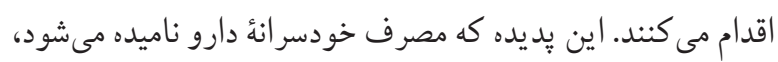
مسئلهاى جهانى است كه، بهويزه، در كشورهاى درحال توسعه شيوع دئن

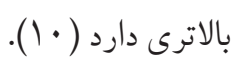
خوددرمانى رفتارى است كه طى آن شخص سعى مى كند بدون

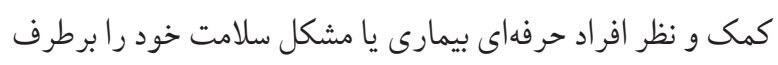


مجاز و شناختهشده مربوط است كه عوارض جانبى كم و ايمنى بالا

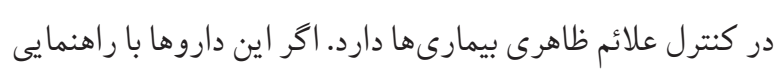

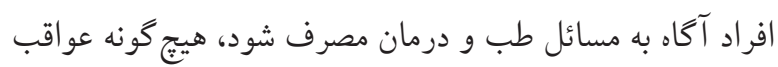



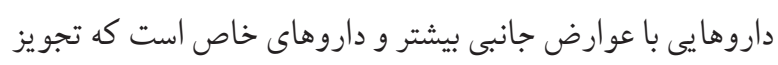
آنها نياز به تشخيص يزشك دارد و بيماران اجازءٔ مصرف خودسرانئ

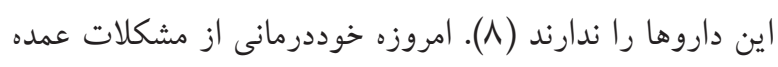

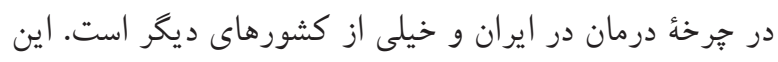


يزشك و 19 مراجعه كننده به مراكز درمانى بود.



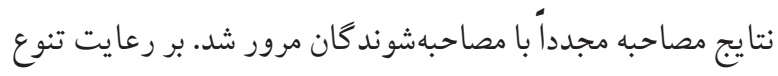
در انتخاب مصاحبهشوندگان سعى شد. همجنين با تنظيم سؤالات

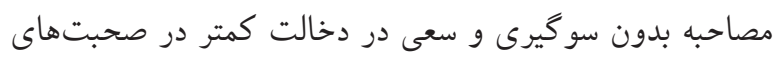

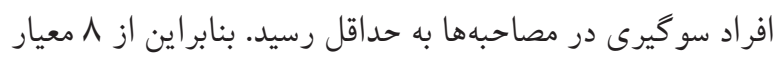
مطرحشده توسط Creswell براى روايى از f ب معيار استفاده شد.

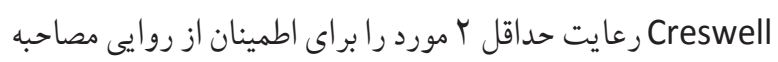

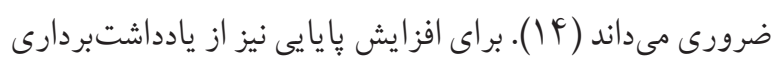
مفصل و كد گذارى توسط جند نفر استفاده شد. تحليل دادهها با استفاده از رو يكرد تئورى دادهبنياد انجام شده توند

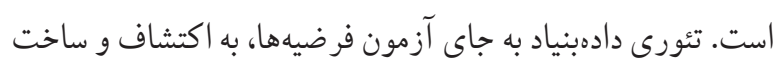

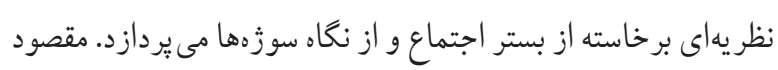
از به كار كيرى تئورى دادهبنياد داشتن نظريهاى است كه بيوند عميق

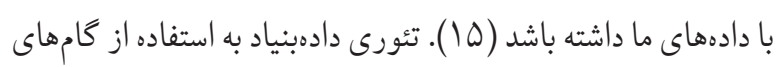


يك الكوى منطقى يا يك توصيف بصرى از نظريةٌ توليدشده تأكيد

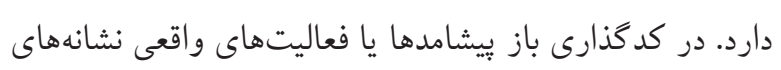

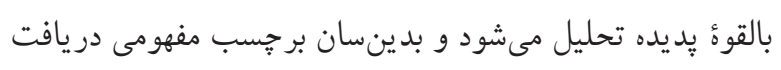

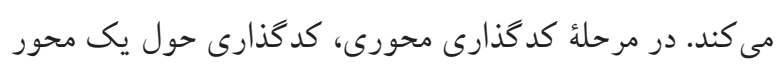

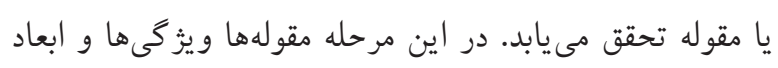

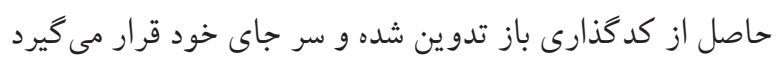

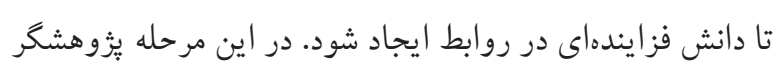
يك مقوله مرحلة كدكذارى باز را انتخاب كرده و آن را، در مركز فرايندى كه در حال بررسى است، يديده مر كزى( Core Category

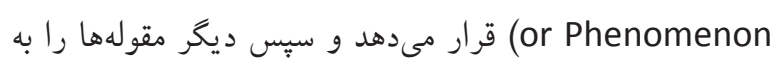

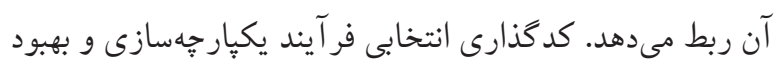

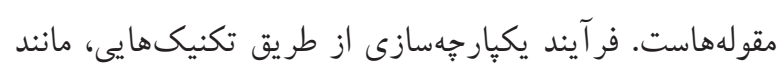



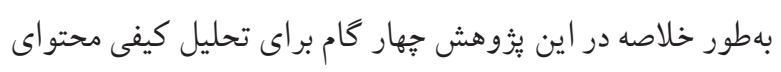



اوضاعواحوال مصرف غيرمنطقى دارو بحرانى است (9). ميزان

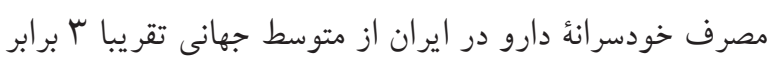
بيشتر است (T) (I). مصرف خودسر انهٔ دارو يكى از معضلات مهم در جهان، از جمله



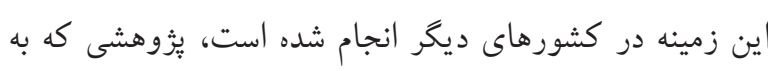

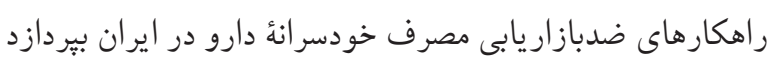

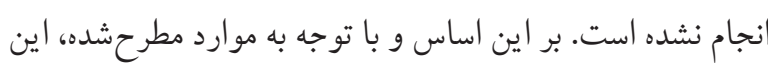

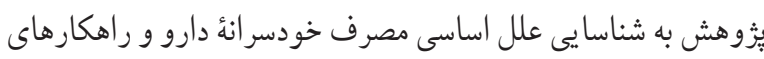

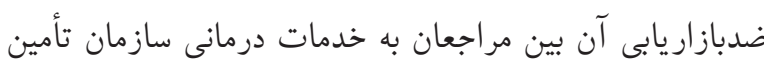

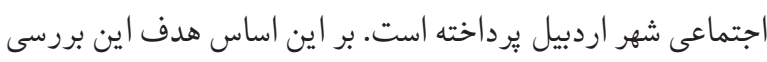

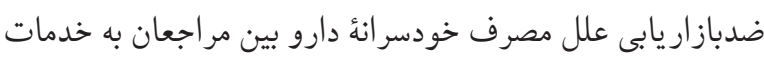
درمانى سازمان تأمين اجتماعى شهر اردبيل است.

$$
\text { روش بررسى }
$$

اين يُزوهش از بعد هدف كاربردى و از لحاظ ماهيت اكتشافى با بردي

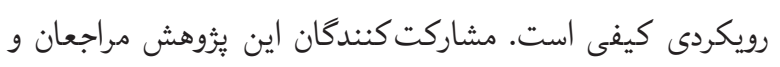

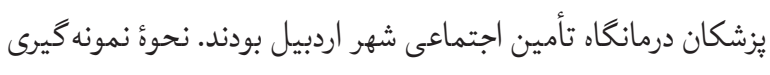

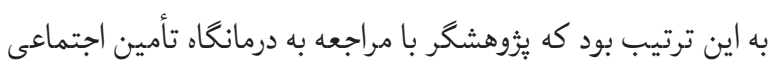

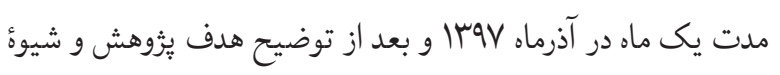



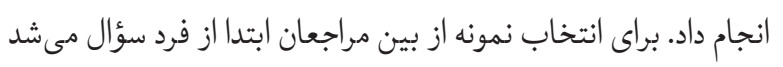

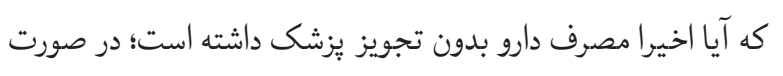
مثبت بودن پاسخ و در صورت تمايل فرد به مصاحبه، فرد بهعنوان

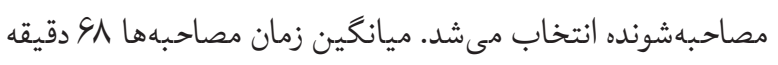

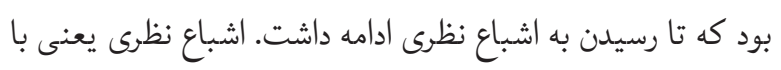

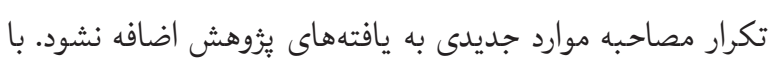
توجه به ماهيت روش تئورى دادهبنياد، جمع آورى و تحليل دادهها همزمان انجام كرفت. به اين ترتيب با انجام هر مصاحبه فرايند

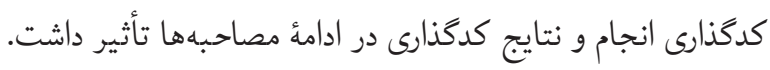

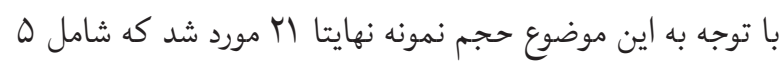






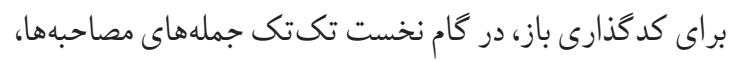
بططور دقيق، تجز يهو تحليل شد و مفاهيم اصلى ظهور كرد. كدكذارى باز

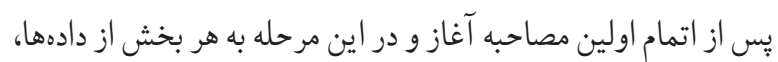

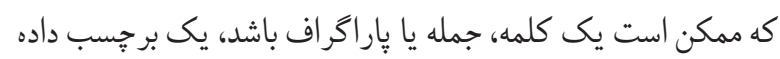

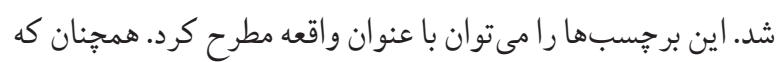

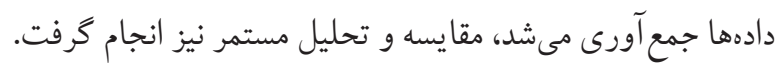

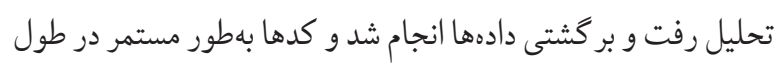

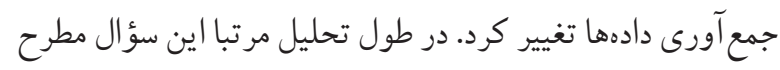

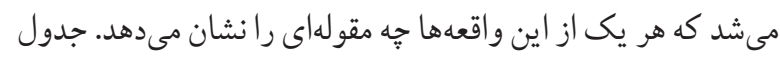

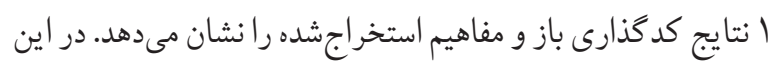
جدول نمونهاى از كفتارهاي مشار كت كند كان و و مفاهيم استخراجشده و نشانكر هر كد مشخص شده است. جدول ا. تعيين كدهاى سطح يك از ََفتارهاى كليدى با كد كَارى باز

\begin{tabular}{|c|c|c|}
\hline 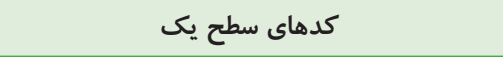 & نمونه كَفتارهاى كليدى & نشانكر \\
\hline اصرار بيماران بر تجويز داروى بيشتر & بيماران درخواست تجويز داروى بيشتر مى كنند. & DA1 \\
\hline تجربة قبلى بيمارى و شناخت آن & اكر يك بيمارى را تجربه كنم بار دوم خودم مىدانم كه جه داروهايى را دصرف كنم. & DA2 \\
\hline 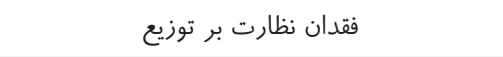 & بر توزيع دارو نظارت خاصى وجود ندارد. & DA3 \\
\hline شلوغى مطب يزشكان يا مراكز درمانى & معمولا مطب يزشكان شلوغ است و زمان زيادى را بايد در آن صرف كنيم كه كاها ارزشش & DA4 \\
\hline نا ن آشنايى با عوارض دارو & 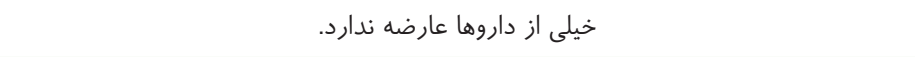 & DA5 \\
\hline استفادة قبلى از دارو و بهبودى علائم & وقتى يك دارو يكبار جواب مىدهد، دفعات بعد هم از همان استفاده مى كنم. & DA6 \\
\hline نداشتن دفتر جهُ بيمةٔ درمانى & هزينهُ ويزيت برايم گران است و وقتى دفتر خه هم نداشته باشى مجبور مىشوى بدون ويزيت & DA7 \\
\hline فروش بدون نسخه در داروخانهها & وقتى دارو راحت بدون نسخه به فروش مىرسد مردم هم راحت مىتوانند آن را بخرند. & DA8 \\
\hline نداشتن اطلاعات لازم در مورد مصرف خودسرانه & خوب اكر بدون نظر يزشك دارو مصرف كنم جهه اتفاقى مىافتد؟ & DA9 \\
\hline ترس و خجالت از معاينات يزشكى & از معاينه مىترسم. از بعضى معاينات هم خجالت مى كشم. & DA10 \\
\hline نداشتن فرصت كافى براى مراجعه به يزشك & خوب مراجعه به يزشك وقت مى خواهد كه كاها ندارم & DA11 \\
\hline توصية افراد غيرمتخصص به فوايد درمانى دارو & 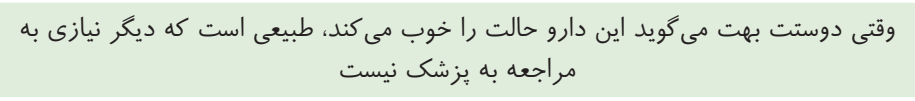 & DA12 \\
\hline نداشتن استطاعت مالى براى يرداخت ويزيت & خوب وقتى بودجهات محدود است ترجيح مىدهى بهجاى هزينهُ ويزيت، دارو بخرى. & DA13 \\
\hline ت توصية داروخانهها & داروخانهها خودشان داروى مناسب بيمارى را به من ييشنهاد مى كنند & DA14 \\
\hline يايين بودن سطح آموزش در جامعه & پايين بودن سطح آموزش مردم را به سمت مصرف خودسرانه سوق مىدهد. & DA15 \\
\hline
\end{tabular}

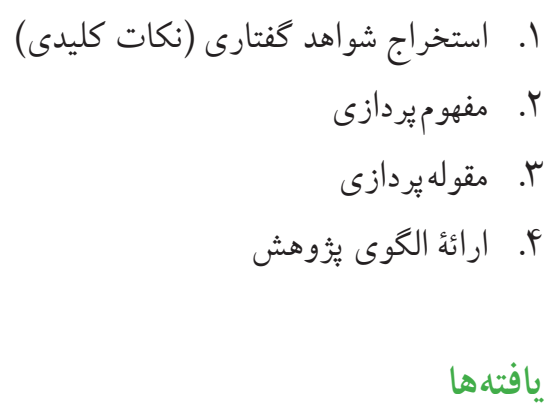

در اين يُؤهش، با توجه به رويكرد تئورى داددبنياد، فرايند جمع آورى

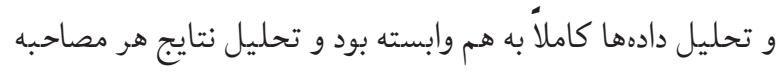

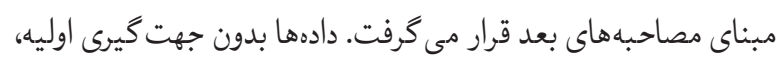
بهاصطلاح بى طرفانه، بررسى شد. مصاحبهها درنهايت آ مصاحبه

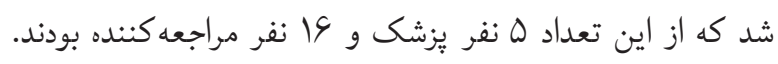

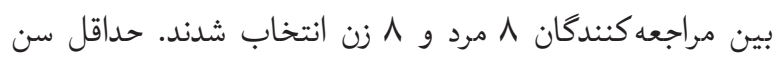

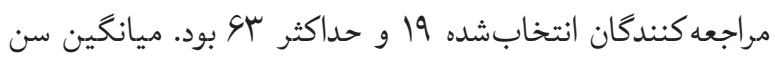


ادامه جدول ا. تعيين كدهاى سطح يك از گفتتارهاى كليدى با كدگذارى باز

\begin{tabular}{|c|c|c|}
\hline اعتقاد به جزئى بودن علائم & خيلى وقتها علائم جزئى بيمارى نيازى به مراجعه به يزشك ندارد & DA16 \\
\hline تجربه داشتن در درمان بيمارىها & قبلاً اين بيمارى را با همين داروها درمان كرديم. & DA17 \\
\hline اعتقاد به تجويز نسخهُ مشابه از سوى يزشك & اگر به يزشك مراجعه كنم همان نسخة قبلى را تجويز مى كند. & DA18 \\
\hline اعتقاد به بىضرر بودن داروى مدنظر & اگر داروى مدنظر بيمارى را درمان نكند، ضر رى هم ندارد. & DA19 \\
\hline اطلاعرسانى ضعيف وزارت بهداشت، درمان و & اطلاعرسانى وزارت بهداشت در خصوص عوارض داروها ضعيف است. & DA20 \\
\hline توزيع دارو در غير از داروخانهها & برخى از داروها حتى در خارج از داروخانهها هم راحت در دسترساند. & DA21 \\
\hline هزينه رفتوآمد به مطب & خوب رفتوآمد به مطب هم خودش هزينهبر است. & DA22 \\
\hline نداشتن اعتماد به يزشكان و مراكز درمانى & خيلى از يزشكان قابل اعتماد نيستند. & DA23 \\
\hline جزئى بودن علائم و نداشتن احساس نياز به يزشك & علائم بيمارى خيلى وقتها آنقدر مهم نيست كه به پزشك مراجعه كنم & DA24 \\
\hline نداشتن زمان كافى براى مراجعه به مطب يا مراكز & خيلى وقت مراجعه به بزشك ندارم. & DA25 \\
\hline 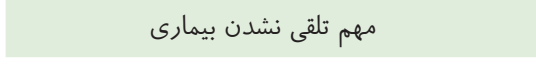 & خيلى از بيمارىها جندان مهم نيستند. & DA26 \\
\hline 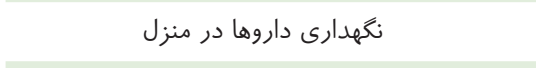 & نكهدارى دارو در منزل و دسترسى آسان به آن مصرف خودسرانهُآن را افزايش مىدهد. & DA27 \\
\hline 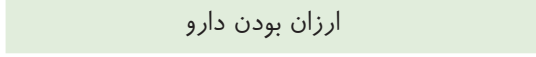 & برخى از داروها ارزان هستند براى همين مردم راحت مىتوانند آنها را تهيه كنند. & DA28 \\
\hline اطمينان از تجويز داروى خاص توسط يزشك & مى دانم اكر به يزشك مراجعه كنم كدام دارو را تجويز خواهد كرد. & DA29 \\
\hline نياز به مراجعة مكرر و اتلاف وقت & با يكبار مراجعه به يزشك درمان نمى شوم و بايد بيشتر مراجعه كنم و اين باعث اتلاف وقت & DA30 \\
\hline دسترسى سريع و آسان به دارو & جون مردم دسترسى راحتى به داروها دارند مصرف خودسرانه دارو را افزايش مىدهد. & DA31 \\
\hline فقدان نظارت در نظام تشخيص و تجويز & نظارت جندانى در مرحلة تشخيص بيمارى و تجويز دارو وجود ندارد. & DA32 \\
\hline فرهنگ نامناسب مصرف دارو در جامعه & فرهنگ درست مصرف دارو وجود ندارد. & DA33 \\
\hline اعتقاد نداشتن به درمان بزشك يا مراكز درمانى & مراكز درمانى و بزشكان نمىتوانند بهطور صحيح بيمارى را درمان كنند. & DA34 \\
\hline 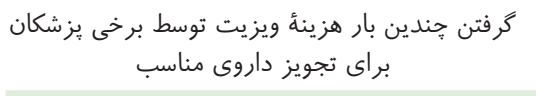 & در درمان يك بيمارى بايد هند بار به يزشك مر مرجعه كرد و هر بار يزشكان حق ويزيت & DA35 \\
\hline دسترسى نداشتن به خدمات بهداشتى ـ درمانى & دسترسى به مراكز درمانى مشكل است. & DA36 \\
\hline كرفتن نتيجة مطلوب از مصرف خودسرانه قبلى & دفعات قبلى كه خودم دارو مصرف كردم، جواب گرفتم. & DA37 \\
\hline  & نبود نظام جامع ارجاعدهى بيمار از دلايل مصرف خودسرانه دارو است. & DA38 \\
\hline نداشتن احساس نياز به مراجعه به يزشك يس از & بعد از اين كه بيمارى تشخيص داده شد ديخر نيازى به مراجعه به يزشك نيست. & DA39 \\
\hline ترس از هزينة بالاى تشخيص & مى ترسم مجبور بشوم هزينة زيادى بابت آزمايشها بيردازم. & DA40 \\
\hline تجويز غير منطقى دارو توسط برخى يزشكان & يزشكان بيشتر اوقات داروى غير منطقى تجويز مى كنند. & DA41 \\
\hline 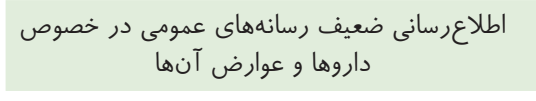 & رسانهاى عمومى در اين زمينه كم كارى مى كنند و اطلاعرسانىهاى ضعيفى دارند. & DA42 \\
\hline 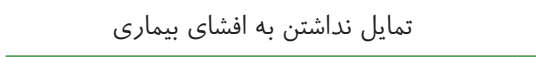 & بعضى وقتها دوست ندارى بقيه متوجه بشوند كه تو بيمارى خاصى دارى. & DA43 \\
\hline
\end{tabular}

با توجه به اين كه هدف اين يثوهش ارائهُ الخو بود، نه نظريهاى دسترسى، تجربه و نگرش، فرهنگى ـاجتماعى، آكاهى، اقتصادى و جهانشمول، در اين مرحله براى دستهبندى مقولات و ارائهُ الخو سعى موانع مرتبط با مراكز درمانى است. جدول ب جزييات كدگذارى شده است عو امل مؤثر در شش كروه دستهبندى شود كه شامل مؤلفههاى انتخابى را نشان مىدهد. اين نتايج در قالب شكل ا جمع بندى شدهاند. 
جدول r. تعيين مفاهيم و مقولهها از كدهاى سطح يك طى مرحله كدگذارى انتخابى

\begin{tabular}{|c|c|}
\hline مقولهها & مفاهيم \\
\hline دسترسى & 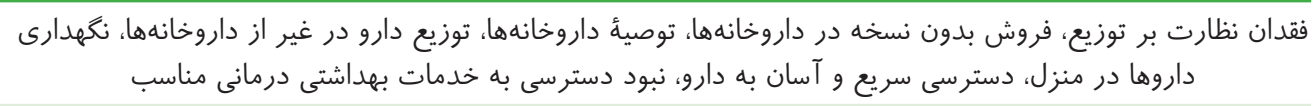 \\
\hline تجربه و نغرش & 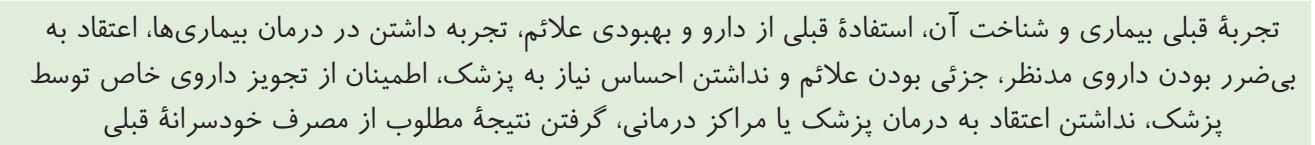 \\
\hline فرهنگى ـ اجتماعى & 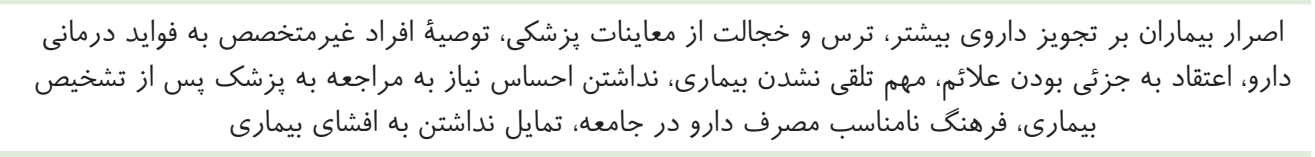 \\
\hline آ آكاهى & 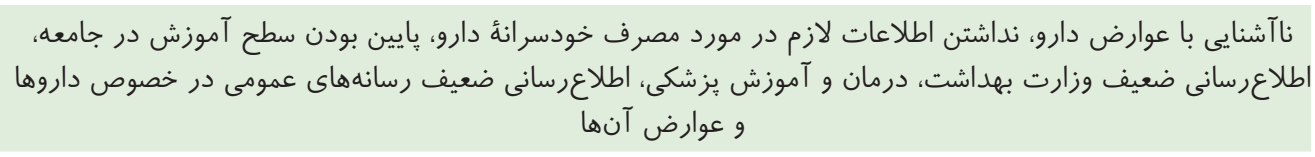 \\
\hline اقتصادى & 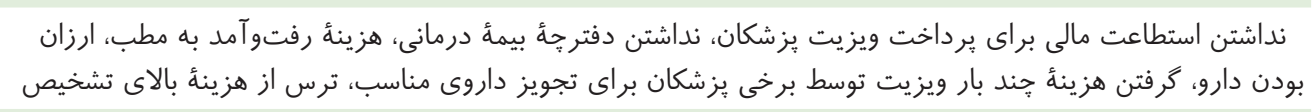 \\
\hline موانع مرتبط با مراكز &  \\
\hline
\end{tabular}

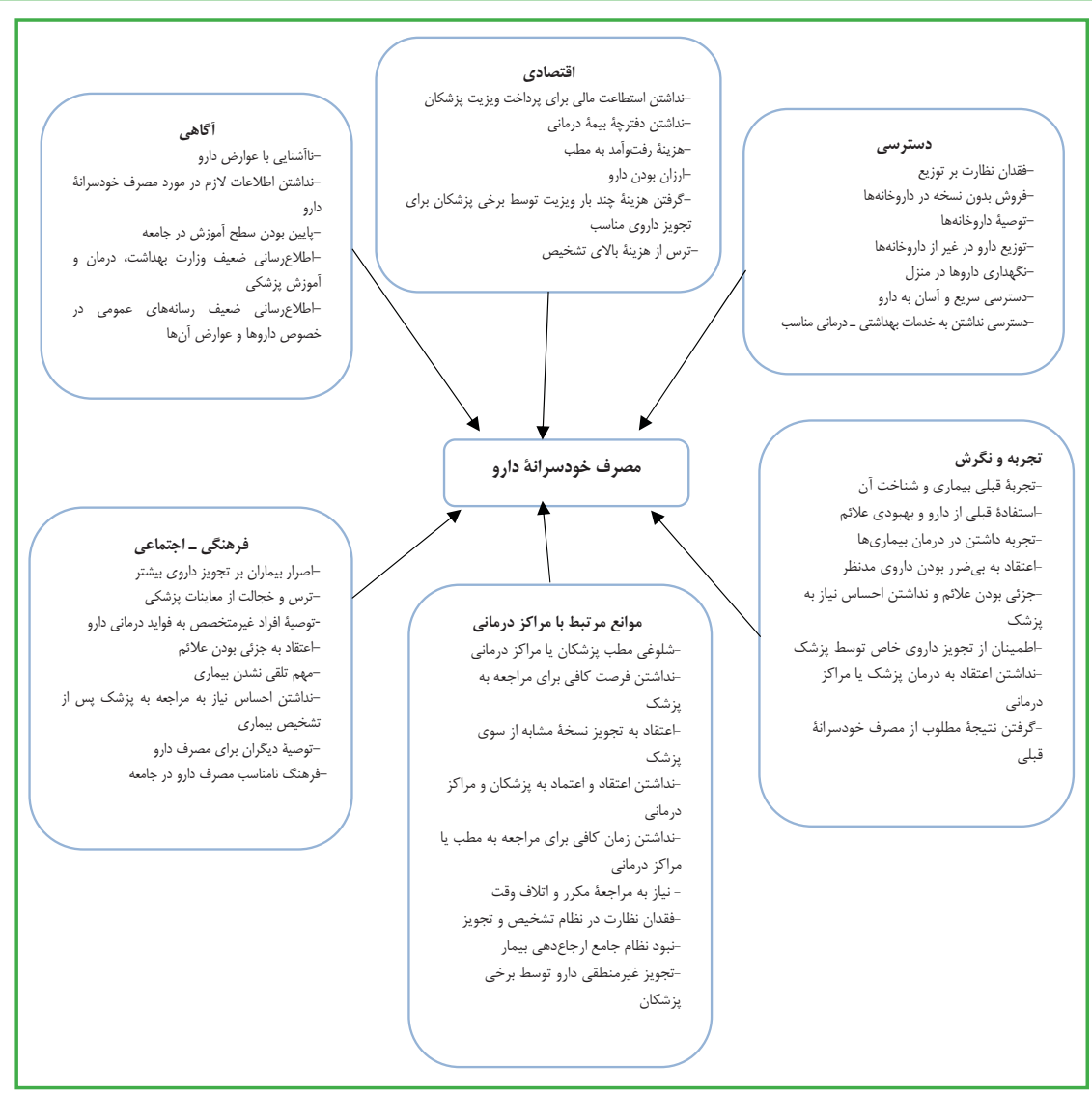

شكل ا. مدل نهايى علل مصرف خودسرانه دارو 


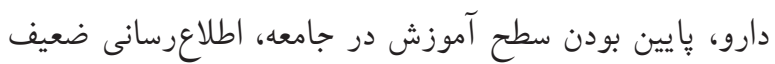

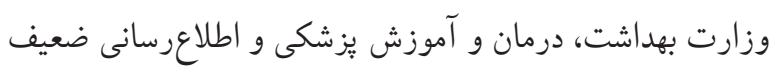
رسانههاى عمومى در خصوص داروهاو عوارض آنهاست. Badiger

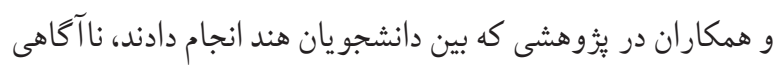

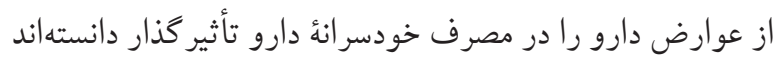

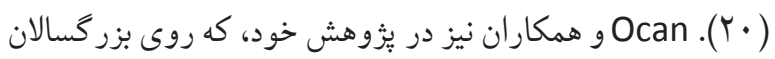

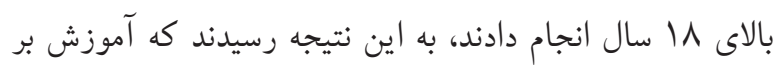


نيز تأثير آكاهى بر خوددرمانى را تأييد كردند (V) (V). بر اين اساس داس مى توان كفت كه يزوهشهاى بيشين نتيجئ اين يُزوهش را تأييد

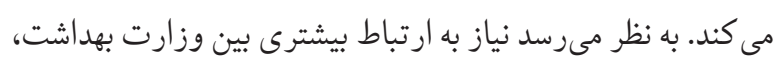

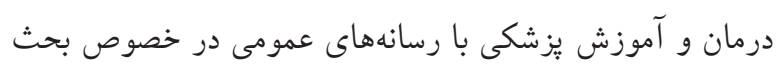

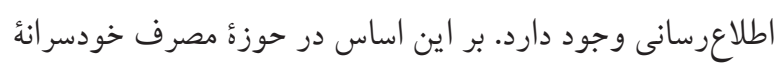

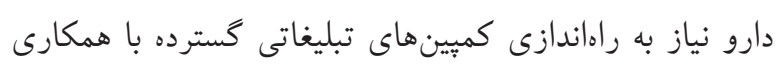
رسانهاى ير مخاطب و نيز شبكهاى اجتماعى احساس مىشود.

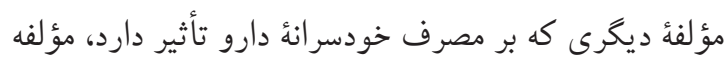
فرهنكى ـ اجتماعى است. شاخصهاى شناسايى شده براى اين مؤلفه

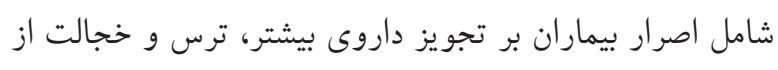



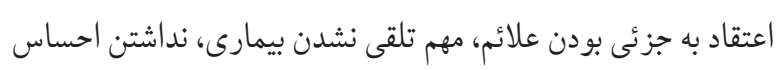



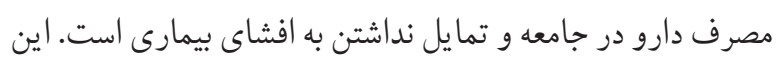



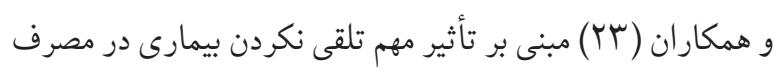

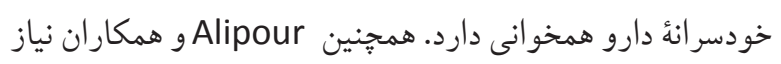



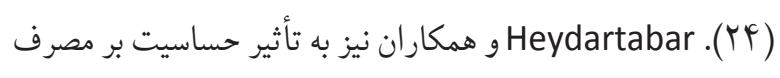


دوستان و خانو اده را عامل مؤثر بر مصرف خودسر انهُ دارو دانستهاند

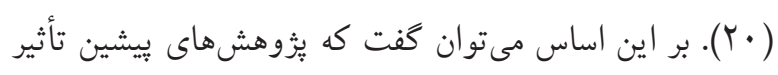

هدف اين يُوهش شناسايى دلايل مصرف خودسرانهُ دارو و راهكارهاى

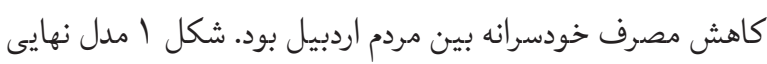

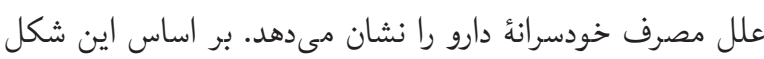

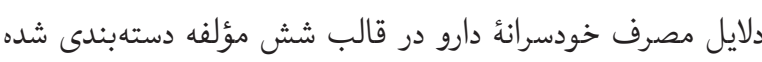


اقتصادى و موانع مرتبط با مراكز درمانى است.

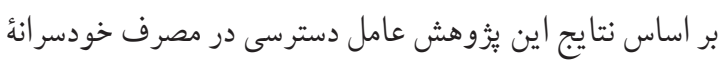

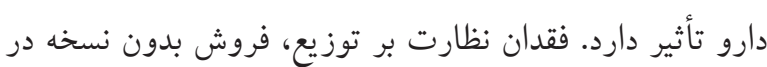

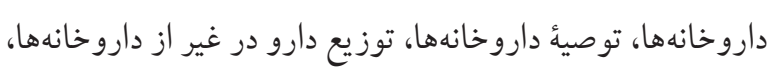

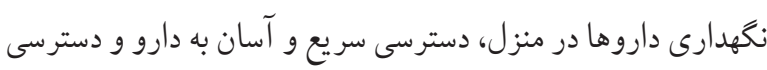

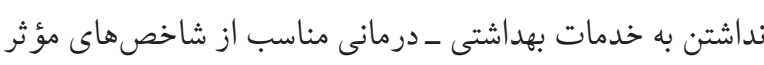

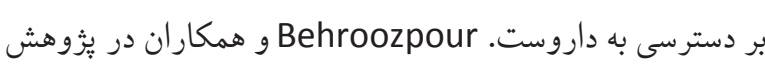

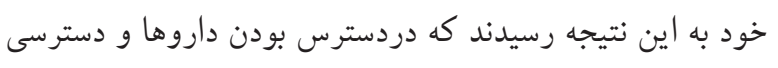

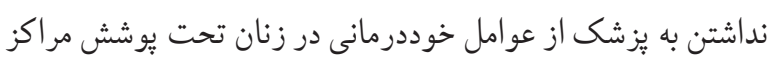

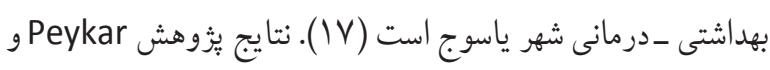




همكاران نيز دسترسى نداشتن به يزشك و دسترسى راحت به دارو دارو

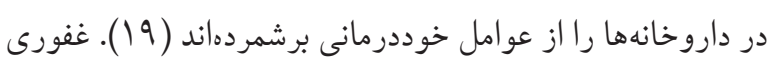

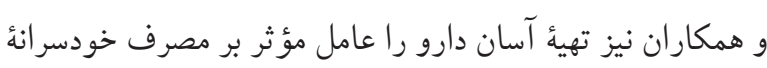

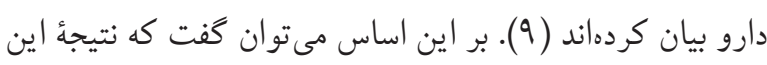
يُّوهش در خصوص تأثير عامل دسترسى در مصرف خودسر انهُ دارو

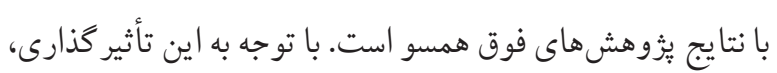

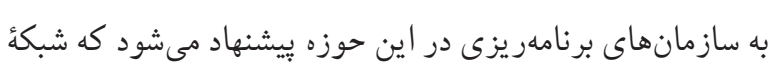

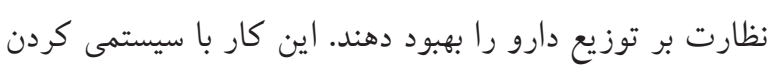

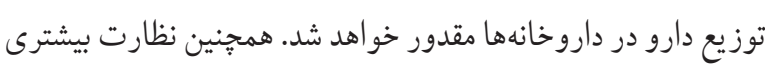
بر فروش آزاد داروهاى بدون مجوز، فروش بدون نسخه و مراكز فروش دارو داشته باشند.

همجِنين اين يُزوهش نشان مى دهد كه آكاهى بر مصرف خودسر انهُ

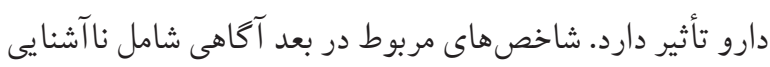


از سوى يزشك را بر خوددرمانى تأييد كردهاند (19). Badiger

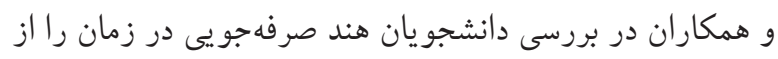

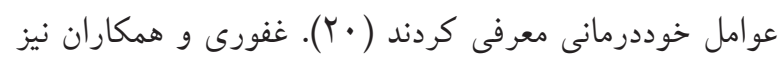
نداشتن اطمينان به طبابت يزشك و نداشتن وقت براى بردئ مر اجعه به

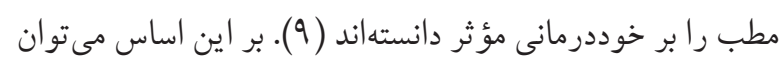

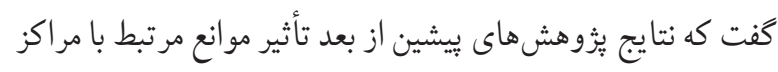



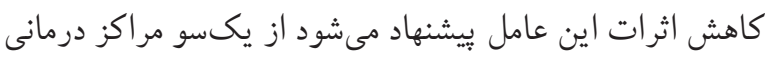

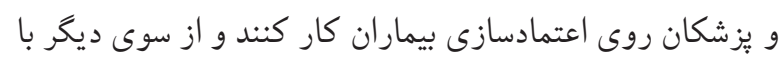

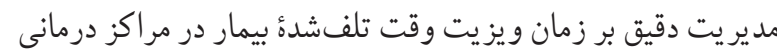

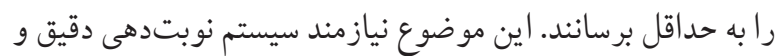
اطلاعرسانى قبلى در صورت تغيير زمان ويزيت است.




بيمارى و شناخت آن، استفادء قبلى از دارو و بهبودى علائم، تجربه نهايه

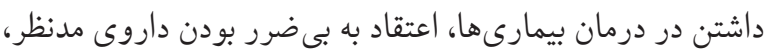

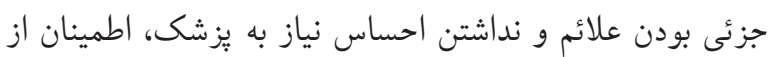

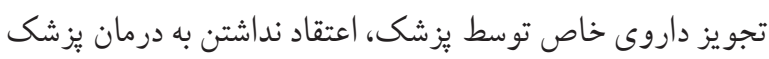



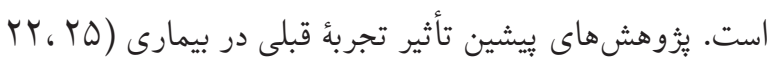
(IV، مصرف دارو (Yr) را بر مصرف خودسر انهُ دارو مؤثر دانستهاند. بر اين اساس اين يُوهش با نتايج يزوهش هاى بيشين همسو است.

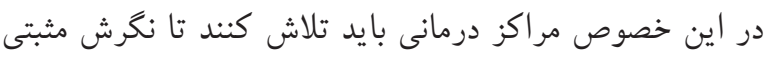

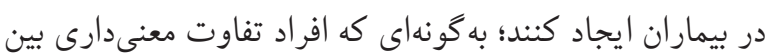
خوددرمانى و درمان از طريق مراكز درمانى مشاهده كنند. نتيجاه كيرى علل مصرف خودسرانهُ دارو بين مراجعه كنندگان به مراكز درمانى تأمين اجتماعى اردبيل در قالب شش مؤلفه دستهبندى شد؛ كه دهرد

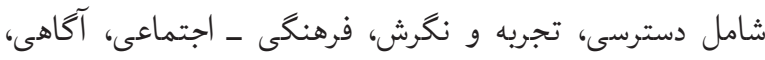

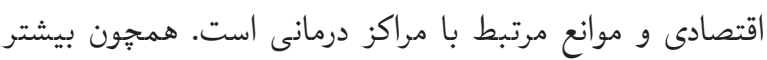

عوامل فرهنكى ـ اجتماعى را بر مصرف خودسرانهُ دارو را تأييد

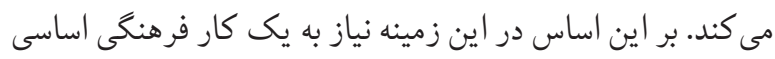
براى بهبود شاخصهاى منفى شناسا يیى شده در جامعه است.

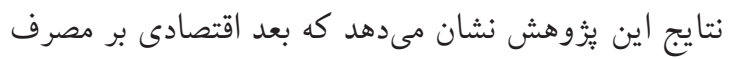

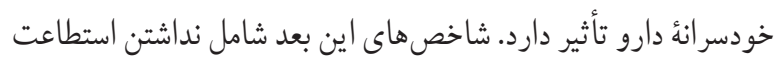
مالى براى يرداخت ويزيت بز شكان، نداشتن دفترجهُ بيمهُ درمانى،

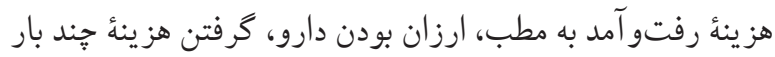

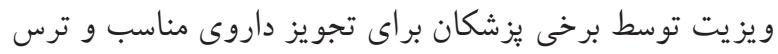



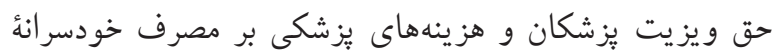





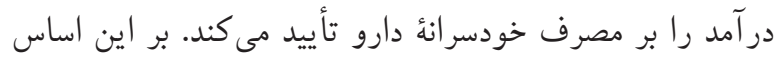

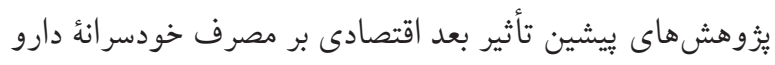

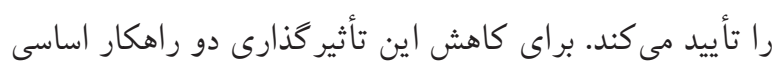
مربوط به كاهش هز ينهاى درمان و نيز كستردگى مكانى مراكز

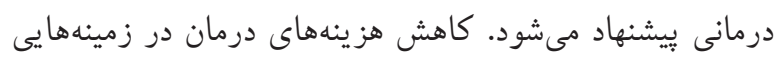

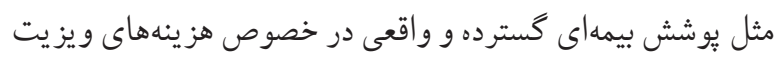



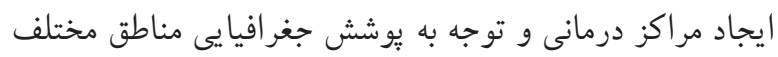
توسط مراكز درمانى است.

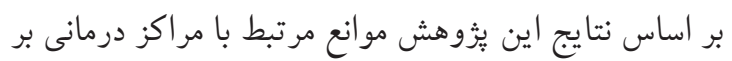

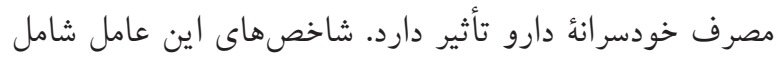

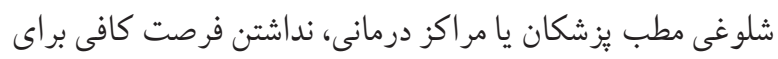

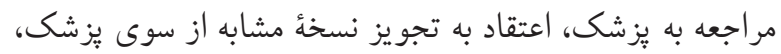

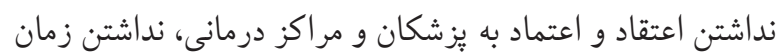
كافى براى مر اجعه به مطب يا مراكز درمانى، نياز به مراجعهُ مكرر

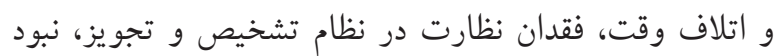

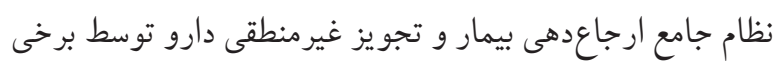

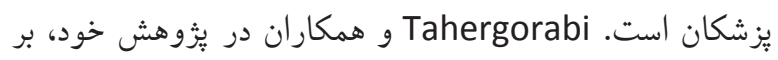

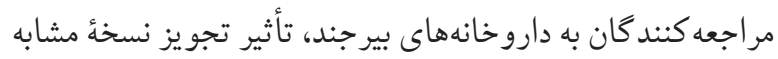




$$
\begin{aligned}
& \text { عوامل را با استفاده از روش هاى كمى در جوامع آمارى ديگر آزمون } \\
& \text { كنند. همجزنين ييشنهاد مىشود يثوهش هاى آتى به اولويتبندى } \\
& \text { اين عوامل از لحاظ ميزان تأثير بر مصرف خودسرانهُ دارو بيردازند. }
\end{aligned}
$$

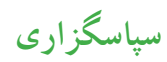

$$
\begin{aligned}
& \text { نويسندكان بر خود لازم مىدانند از همة كسانى كه در طول اين } \\
& \text { يزوهش با يزوهشكران همكارى داشتهاند، از جمله كاركنان درمانگاه } \\
& \text { تأمين اجتماعى اردبيل و نيز همهُ مشاركت كنندگان، تشكر كنند. } \\
& \text { تقارض در منافع } \\
& \text { بين نويسندگان هيج گونه تعارضى در منافع وجود ندارد. }
\end{aligned}
$$

\section{References}

1. Kotler P, Armstrong G. Principles of Marketing, translated by Bahman Foroozandeh.

2. Peattie K, Peattie S. Social marketing: A pathway to consumption reduction?. Journal of Business Research. 2009 Feb 1;62(2):260-8. https://doi.org/10.1016/j.jbusres.2008.01.033

3. Wall AP. Government demarketing: different approaches and mixed messages. European Journal of Marketing. 2005 May 1;39(5/6):421-7. https://doi.org/10.1108/03090560510590647

4. Sodhi K. Has marketing come full circle? Demarketing for sustainability. Business strategy series. 2011 Jul 5;12(4):177-85. https://doi.org/10.1108/17515631111155133

5. Rezaei Jaberee S, Hassani L, Aghamolaei T, Mohseni S, Islamic H. Study on the Effect of Educational Intervention based on Health Belief Model to Prevent the Arbitrary Use of Drugs in Women Referring to Health Centers of Bandar Abbas. Iranian Journal of Health Education and Health Promotion. 2018 Apr 15;6(1):1-1.

6. Aminshokravi F, Tavafian S, Moayeri A. Assessing Related Factors on the Illicit Use of Medications in Abbas Abad City (mazandaran): A Cross Sectional Study. scientific journal of ilam university of medical sciences. 2014 Oct 15;22(5):119.

7. Heydaratabar R, Hatefnia E, Kazem Nezhad A. The Knowledge and Factors Associated with Self-Medication Behavior of Mothers with Children Under Two Years Have Referred to Health Centers in City of Firuoz Kuh Based on the Health Belief Model. aumj. 2016; 5 (2) :95-102 https://doi.org/10.18869/acadpub.aums.5.2.95. URL: http://aums.abzums.ac.ir/article-1-420-fa.html
يثوهش هاى ميدانى، اين يثوهش نيز محدوديتهايى دارد؛ از جمله


در شهر اردبيل انجام شد و با توجه به مباحث فرهنگى خاص هر جامعه ممكن است علل شناسايىشده و راهكارهاى ييشنهادشده براى ساير جوامع كاملا منطبق نباشد، لذا استفاده از آن براى ساير جوامع بايد باحتياط صورت گيرد. ديخر محدوديت يزوهش كمبود ييشينهُ كافى در اين زمينه بود. اين يزوهش به شناسايى عوامل اساسى مؤثر بر مصرف خودسرانه دارو در اردبيل يرداخت. ييشنهاد مىشود يثوهشهاى بعدى اين

8. Jalilian F, Hazavehei SM, Vahidinia A, Moghimbeigi A, zinat MF, mirzaei AM. Study of causes of self-medication among Hamadan Province Pharmacies Visitors. Journal of Hamadan University of Medical Sciences \& Health Services. 2013; 20(2): 160-166.

9. Ghafouri M, Yaghubi M, Lashkardoost H, Seyed SharifiSH. The prevalence of self medication among students of Bojnurd universities and its related factors in 2013. Journal of North Khorasan University of Medical Sciences. 2013;5:1136. https://doi.org/10.29252/jnkums.5.5.S5.1129

10. Ahmadi S, Mokhtari M, Karimian S. Sociological Analysis of Gender Differences on Self-Medication in Yasouj. Journal of Women and Society. 2017; 8(3): 33-50.

11. Mahdavinoor H, Donkob M. Programming Modification of Drug Consumption Pattern Based on Religious Teachings, National Interests, and Attention to Deprived People. Hakim Health Sys Res . 2017; 20 (1) :17-26

12. Rahbar A, Gharlipour Z, Arsang JS, Ebrazeh A, Kazazlou Z. Perceived Benefits and Barriers about Self-medication among Women Referring to Health Center in Qom City2016.

13. Margdari Nejad M, Kazemi SB, Khosravi M, Sanagoo A, Jouybari L. The Prevalence of Non-Prescription Drugs and Related Factors in Students of Medical Sciences in 1392. Iran Journal of Nursing. 2017 Feb;29(104):66-74. https://doi.org/10.29252/ijn.29.104.66

14. Creswell JW, Poth CN. Qualitative inquiry and research design: Choosing among five approaches. Sage publications; 2017 Jan 10.

15. Valibeyghi H. Promotional Policies for Exports of High-Tech Industries in Selected Countries. Quarterly Commercial Reviews. 2009;37:9-28. 
16. Zarei G, Parsamehr B. Identification of effective factors on the development of export of medical equipment using grounded theory. Journal of Healthcare Management; 2018 Nov 22; 9(3):7-17.

17. Behroozpour A, Shams M, Mousavi M, Ostovar R, Maleki M. Self-Medication Among Women in Yasouj City and Factors Associated with it: A Preliminary Study for Designing an Intervention Based on Health Belief Model. Journal of School of Public Health and Institute of Public Health Research. 2016 Dec 15;14(3):97-108.

18. Peykar Z, Mohammadi A. Economic and Institutional Factors Affecting Self Curing and Self-medication in Shahrekord. Healthy breeze. 2016; 4(4):7-14.

19. Tahergorabi Z, Kiani Z, Moodi M. Epidemiological study of self-medication and its associated factors in visitors to Birjand pharmacies, 2015. Journal of Birjand university of medical sciences. 2016; 23(2):158-169.

20. Badiger $S$, Kundapur R, Jain A, Kumar A, Pattanshetty $S$, Thakolkaran N, Bhat N, Ullal N. Self-medication patterns among medical students in South India. The Australasian medical journal. 2012;5(4):217. https://doi.org/10.21767/AMJ.2012.1007 https://doi.org/10.4066/AMJ.2012.1007 PMid:22848313 PMCid:PMC3395275

21. Ocan M, Obuku EA, Bwanga F, Akena D, Richard S,
Ogwal-Okeng J, Obua C. Household antimicrobial selfmedication: a systematic review and meta-analysis of the burden, risk factors and outcomes in developing countries. BMC public health. 2015 Dec;15(1):742. https://doi.org/10.1186/s12889-015-2109-3 PMid:26231758 PMCid:PMC4522083

22. Rezayi JS, Hasani L, mohseni S. The Prevalence of selfmedication and identify the reason of it in women referring to health centers in Bandar Abbas 2016. Scientific Journal of the Medical Council of the Islamic Republic of Iran. 2016; 34(1): 53-61.

23. Najafipour R, Shishehbor F, Ahmadinia H, Rezaeian M. The Frequency of Self-Medication in Medical Students of Rafsanjan University of Medical Sciences in 2016. Journal of Rafsanjanuniversity of medical sciences. 2017; 17:331344.

24. Alipour Z, Eskandari N, Izadi Tamhe A, Faezipour A, Abedini Z, Khoramirad Rad A. Relationship between personality characteristics and use of antibiotics. Journal of Holistic Nursing And Midwifery. 2015 Sep 15;25(3):46-54.

25. Afshary P, Mohammadi S, Koshteh S, Pajohideh SZ, Tabesh $\mathrm{H}$. Survey on prevalence and causes of self-medication in women referring to health centers in Ahwaz, in 2013. ISMJ. 2015 Nov 15;18(5):1034-44. 